\title{
Water Governance in the Aftermath of Rio+20
}

\author{
Francesco Sindico \\ Reader in International Environmental Law, University of Strathclyde, UK \\ Director, Strathclyde Centre for Environmental Law and Governance
}

\begin{abstract}
This paper focuses on water governance in the aftermath of the 2012 United Nations Conference on Sustainable Development (UNCSD or Rio+20). Water governance is defined here as a process in which law has a transformational role by allowing policy goals to become tangible and enforceable rights and obligations. Against this conceptual background global water governance appears to be still fragmented and incoherent. More coordination efforts and further harmonisation is needed, but more importantly global institutions are required to allow international law to operate effectively. It is within this context that the UNCSD can be seen as an international agenda setting process and three key water related topics appear to be on such agenda: water and sanitation; water and ecosystem services and water and climate change. The paper concludes with a call in favour of considering water not just as a public good, but mainly as a driver for sustainable development.
\end{abstract}

\section{Keywords}

Water governance, Rio+20, international law, sustainable development

\section{Introduction}

It is difficult to think of another natural resource as important as water. The latter is essential for life on earth, not only for humans, but also for animals and, more broadly, for healthy ecosystems on the planet. For humans water is not only crucial for quenching their natural thirst, but is a key input for agriculture and numerous industrial activities. Furthermore, both non-renewable and renewable energy require vast amounts of water. The $21^{\text {st }}$ century is therefore seeing an increasing attention to multiple challenges to water resources coming from the water/energy and water/food nexus. ${ }^{1}$ The relevance of water

\footnotetext{
${ }^{1}$ See Morgan Bazilian et al., "Considering the energy, water and food nexus: Towards an integrated modelling approach”, 39 Energy Policy (2011), p. 7896.
} 
for key human activities has led in the past to consider that future wars will be fought over this natural resource, ${ }^{2}$ rather than over oil or minerals. Some argue that this is already happening. ${ }^{3}$ This dimension adds to the water debate a security aspect, which makes it even more important that States, and all stakeholders more generally, do not compete over scarce water resources, but cooperate in their management. The United Nations (UN) made this call for cooperation very clear when in 2010 it decided that 2013 would be the International Year of Water Cooperation. ${ }^{4}$

Against this background, this paper focuses on water governance in the aftermath of the 2012 United Nations Conference on Sustainable Development (UNCSD or Rio+20). Water governance is defined here as a process in which law has a transformational role by allowing policy goals to become tangible and enforceable rights and obligations. Against this conceptual background global water governance appears to be still fragmented and incoherent. More coordination efforts and further harmonisation is needed, but more importantly global institutions are required to allow international law to operate effectively. It is within this context that the UNCSD can be seen as an international agenda setting process and three key water related topics appear to be on such agenda: water and sanitation; water and ecosystem services and water and climate change. The paper concludes with a call in favour of considering water not just as a public good, but mainly as a driver for sustainable development; hence, worthy of featuring prominently as a future Sustainable Development Goal (SDG).

The paper is divided in four sections. Section 2 defines governance, water governance, global water governance and assesses the role of law and international law

\footnotetext{
${ }^{2}$ Vandana Shiva, Water wars: Privatization, Pollution and Profit (2002).

${ }^{3}$ James Fergusson, The World's Most Dangerous Place: Inside the Outlaw State of Somalia (2013).

${ }^{4}$ UN Doc. A/RES/65/154, International Year of Water Cooperation, 2013, 20 December 2010.
} 
therein. Section 3 critically assesses the outcome of the Rio +20 Conference from a water context. Finally, the last section draws some conclusions and makes an appeal for considering water prominently in the UN post-2015 agenda.

\section{Global Water Governance and International Law}

\subsection{From Governance to Global Water Governance}

Referring to groundwater, governance has been defined as:

... the process by which groundwater is managed through the application of responsibility, participation, information availability, transparency, custom, and rule of law. It is the art of coordinating administrative actions and decision making between and among different jurisdictional levels - one of which may be global. ${ }^{5}$

Governance is first and foremost construed as a process. Water governance is therefore the process by which water resources are managed and can be defined as the "art" of coordinating water related measures at a sub-national, national, regional or global level. "Good" governance can be seen as a "regulatory system that shows qualities of accountability, transparency, legitimacy, public participation, justice, efficiency, the rule of law, and an absence of corruption". ${ }^{6}$ By linking the definitions of groundwater governance and the one of good governance to water, an image of good water governance can be construed. This would entail a process by which water resources are managed. This process can be characterised as a regulatory system underpinned by a series of

\footnotetext{
5 Robert G. Varady et al., Groundwater Policy and Governance, Groundwater Governance Project Thematic Paper No. 5 (2013), p. 7, emphasis added. This definition of groundwater governance is adapted from the definition of governance provide for by Richard E. Saunier and Richard A. Meganck, Dictionary and Introduction to Global Environmental Governance (2007).

${ }^{6}$ Ibid, p. 13.
} 
principles, which would include, inter alia, public participation, transparency, efficiency, and the others mentioned in the definition of good governance stated above. ${ }^{7}$

The attempt to come up with a definition of water governance is ultimately an academic exercise, as there is no universal common definition of what governance is, or, indeed, of what water governance is. ${ }^{8}$ However, what is clear is that the emergence of the concept of governance itself in the last decades signals something very important. ${ }^{9}$ The State is no longer the sole and primary subject dealing with the management of water resources, but is currently accompanied by a number of other public and private actors and networks.

Moving from water governance to global water governance, the question becomes whether a process through which international waters are managed can be identified at an international level. ${ }^{10}$ Pahl-Wostl, Gupta and Petry have identified six important aspects of this process that can be identified as global water governance: ${ }^{11}$ international law, ${ }^{12}$ permanent global intergovernmental agencies, ${ }^{13}$ developments stemming at a regional

\footnotetext{
${ }^{7}$ Ibid

${ }^{8}$ Ibid p. 7 have undertaken a thorough revision of respected sources on the term "governance" and have identified no less than three dozen key words that can be associated with this concept.

${ }^{9}$ Claudia Pahl-Wostl, Joyeeta Gupta and Daniel Petry, "Governance and the Global Water System: A Theoretical Exploration” 14 Global Governance (2008), p. 423: “...governance involves a multilevel, polycentric condition where many actors in different institutional settings contribute to policy development and implementation."

${ }^{10}$ A further preliminary problem is what can and should be labelled as "international waters". A narrow approach would include only transboundary surface water and transboundary aquifers, while a wider approach may start looking at virtual water and water resources in one country that may be of interest to other countries in light of an emerging human right to access to water and sanitation.

${ }^{11}$ Pahl-Wostl, Gupta and Petry, supra note 9, pp. 425-427.

${ }^{12}$ Examples could include the United Nations Convention on the Law of the Sea, Montego Bay, 10 December 1982 (entered into force on 16 November 1994) and the United Nations Convention on the Law of Non-Navigational Uses of International Watercourses (United Nations Watercourses Convention), New York, 21 May 1997 (not in force).

${ }^{13}$ Permanent intergovernmental agencies include entities such as the UN Education, Scientific and Cultural Organisation (UNESCO) or the United Nations Environment Programme. UN Water was established in 2003 to supervise the implementation of the water related commitments present in the Millennium Development Goals and in the 2002 World Summit on Sustainable Development.
} 
level, ${ }^{14}$ international multistakeholder platforms, ${ }^{15}$ forms of private governance ${ }^{16}$ and global communities of scientists and water professionals. ${ }^{17}$ The picture of global water governance that stems from the combination of the above-mentioned aspects is "diffuse, heterogeneous and fragmented". ${ }^{18}$ The same authors have labelled global water governance as "mobious web-type governance". ${ }^{19}$

\subsection{From Global Water Governance to Global Water Law}

The question then becomes whether law has any role to play in global water governance. And, in particular, whether international law is central to global water governance or not. Leading authors such as Dellapenna and Gupta, ${ }^{20}$ and Mechlem, ${ }^{21}$ agree that law is one of the elements that define water governance. Mechlem in particular presents a compelling picture by maintaining (in reference to groundwater governance) that

[1] egal frameworks play a crucial role for effective groundwater governance. They provide the basis and starting point for policy development and they turn policy decisions into rights and obligations. ${ }^{22}$

\footnotetext{
${ }^{14}$ The European Water Initiative set up in 2002 is an example of a regional development.

${ }^{15}$ The leading international multistakeholder platform is the World Water Council that organises a World Water Forum every three years, with the next one set to take place in South Korea in 2015.

${ }^{16}$ Private water governance refers to transnational water corporations (Suez, Vivendi, etc.), which have emerged as key stakeholders once water services have been privatised in many countries across the world.

${ }^{17}$ Global communities of scientists and water professionals include, amongst others, the Global Water Partnership and the International Water Resources Association. Despite their presence, the global community of scientists in the water sector has not reached the sophisticated level of organisation and of influence it has, for example, within climate change governance. See on this point Pahl-Wostl, Gupta and Petry, supra note 9, p. 427.

${ }^{18}$ Ibid., p. 427

${ }^{19}$ Ibid.

${ }^{20}$ Joseph Dellapenna and Joyeeta Gupta, “Towards Global Law on Water”, 14 Global Governance (2008), p. 437.

${ }^{21}$ Kerstin Mechlem, Legal and Institutional Frameworks, Groundwater Governance Project Thematic Paper No. 5 (2013).

${ }^{22}$ Ibid., p. 5, emphasis added.
} 
Law has therefore a transformational role in the context of water governance. It takes policy decisions, which in themselves may be general and only provide guidance, and converts them into more tangible and enforceable rights. For this to be the case, water governance must be "good" 23 and "fair", which implies that rights and obligations must be clear and predictable. ${ }^{24}$

The transformational role of law in the context of water governance is easier to understand at a domestic level in countries with strong institutions. ${ }^{25}$ It will be more difficult to grasp in countries that lack the necessary institutional structure. If a country lacks administrative powers capable of monitoring the implementation of the obligations and/or an independent judiciary that can be freely accessed, then it will be difficult for law to be an effective part of water governance.

The transformational role of law in the context of water governance is also difficult (but not impossible) to understand in the context of international law. The latter distinguishes itself from national law for the absence of a central legislating power, an absence of a strong enforcement agency and the lack of a supreme judicial body. ${ }^{26}$ Furthermore, States are still International Law's main subjects. ${ }^{27}$ However, as described by Pahl-Wostl, Gupta and Petry, international law is one aspect of current global water governance. ${ }^{28}$ One of the conceptual problems when referring to international law in the

\footnotetext{
${ }^{23}$ According to the definition provided earlier in this section, see Robert G. Varady et al., supra note 5.

${ }^{24}$ Thomas Franck, Fairness in International Law (1995), p. 30. In his seminal piece the author refers to the concept of "determinacy".

${ }^{25}$ Institutions in this context include governmental organisations belonging to the executive and judicial branches of the State.

${ }^{26}$ See Philip Allott, "The Concept of International Law", 10 European Journal of International Law (1999), p. 31 and Malcolm Shaw, International Law (6th ed., 2008), pp. 1-13.

${ }^{27}$ Despite the fact that it is now clear that the State is not the only subject of international law anymore, see Anna-Karin Lindblom, Non-Governmental Organisations in International Law (2005).

${ }^{28}$ See supra note 12. The 1982 UN Convention on the Law of the Sea and the 1997 UN Convention on the Law of the Non-Navigational Uses of International Watercourses are cited as "statist constructions" falling under the International Law aspect of global water governance.
} 
context of water governance (but not only) is that there is a very thin line between international law and policy. ${ }^{29}$ If we go back to Mechlem's approach according to which "legal frameworks... provide the basis and starting point for policy development and they turn policy decisions into rights and obligations", ${ }^{30}$ international law does not always provide for very clear rights and obligations, but, in some cases, only points out general principles, guidelines and recommendations. This is the case in particular when a specific issue is governed only by soft law. ${ }^{31}$ However, if a principle has acquired a customary international law status, ${ }^{32}$ then rights and obligations will stem from such principle, notwithstanding its presence in a soft or hard law legal framework. Having said this, what becomes crucial is the availability of institutions at a global level capable of enforcing and defending these water related rights and obligations and to which States and other subjects of international law (including individuals) can have access to.

Linking these considerations about the role of law in water governance with global water governance, one can appreciate that, despite cooperation over water going back centuries, if not millennia, ${ }^{33}$ this has mainly taken place at basin level. The first efforts to promote a global agenda on water more broadly conceived are instead very recent. The

\footnotetext{
${ }^{29}$ See Martti Koskenniemi, The Politics of International Law (2011) and Martti Koskenniemi, "The Politics of International Law", in Jorge Cardona (ed.), VIII-IX, Cursos Euromediterraneos Bancaja de Derecho Internacional (2004/2005), (2009).

${ }^{30}$ Mechlem, supra note 22.

${ }^{31}$ Soft law in International Law tends to be considered as non-legally binding international legal instruments; i.e. a UN General Assembly Resolution or a Memorandum of Understanding between two countries. However, the differences between hard and soft law is much more nuanced. On the concept of soft law and whether it can (or even should) be considered "law" at all see Alan Boyle, "Soft Law in International Law-Making", in M. Evans (ed.), International Law (3 ${ }^{\text {rd }}$ ed., 2010), pp. 122-140; László Blutman, "In the Trap of a Legal Metaphor: International Soft Law", 59 International and Comparative Law Quarterly (2010), p. 605; and Francesco Sindico, "Soft Law and the Elusive Quest for Sustainable Global Governance", 19.3 Leiden Journal of International Law (2006), p. 829.

${ }^{32}$ Customary international law is present when a rule is complied with by subjects of international law despite the absence of any formal (treaty) provision that would oblige States to do so (subjective element), and this practice occurs over a constant period of time (objective element). See Hugh Thirlway, "The sources of international law", in M. Evans (ed.), International Law ( $3^{\text {rd }}$ ed., 2010).

${ }^{33}$ See infra section 3.
} 
1977 United Nations Water Conference in Mar del Plata is probably one of the first, if not the first, gathering of States and key stakeholders to discuss water at a global level. ${ }^{34}$ From then on attention for water increased and, in the wake of the 1992 Earth Summit, experts gathered in Dublin for the International Conference on Water and the Environment. ${ }^{35}$ The outcome of this conference, the Dublin Statement on Water and Sustainable Development, provided four guiding principles, which were supposed to move forward international cooperation on water. ${ }^{36}$

At the UNCED in Rio in 1992, despite the fact that water did not feature directly in the Rio Declaration on Environment and Development, ${ }^{37}$ it did have a space of its own in the Agenda $21,{ }^{38}$ which provided a roadmap to all interested parties on how to implement the Rio Declaration. ${ }^{39}$ From then on water acquired mainstream importance at international conferences and access to water and sanitation appeared in the Millennium Declaration $^{40}$ and became part of one of the MDGs. ${ }^{41}$ Water also had its place in the

\footnotetext{
${ }^{34}$ UN Doc. E/CONF.70/29, Report of the United Nations Water Conference, Mar del Plata, 14-25 March 1977.

${ }^{35}$ The International Conference on Water and the Environment took place in Dublin from 26 and 31 January 1992 and brought together more than 500 people including government designated experts coming from more than one hundred countries.

${ }^{36}$ Dublin Statement on Water and Sustainable Development: "Fresh water is a finite and vulnerable resource, essential to sustain life, development and the environment; Water development and management should be based on a participatory approach, involving users, planners and policy-makers at all levels; Women play a central part in the provision, management and safeguarding of water; and Water has an economic value in all its competing uses and should be recognized as an economic good."

${ }^{37}$ UN Doc. A/CONF.151/6/Rev.1, Rio Declaration on Environment and Development, 31 International Legal Materials (1992), p. 874.

${ }^{38}$ Agenda 21, Chapter 18 "Protection of the quality and supply of freshwater resources; application of integrated approaches to the development, management and use of water resources".

${ }^{39}$ Seven areas were identified at the time as a priority on which to focus on: "Integrated water resources development and management (IWRM); Water resources assessment; Protection of water resources, water quality and aquatic ecosystems; Drinking-water supply and sanitation; Water and sustainable urban development; Water for sustainable food production and rural development; Impacts of climate change on water resources."

${ }^{40}$ Millennium Declaration, para. 23: "We resolve [t]o stop the unsustainable exploitation of water resources by developing water management strategies at the regional, national and local levels, which promote both equitable access and adequate supplies."

${ }^{41}$ Within MDG 7 "Ensure Environmental Sustainability" target 7.C was to "[h]alve, by 2015, the proportion of the population without sustainable access to safe drinking water and basic sanitation."
} 
Johannesburg Summit on Sustainable Development in 2002 and in the Johannesburg Plan of Implementation. ${ }^{42}$ There a call was made encouraging to:

Promote effective coordination among the various international and intergovernmental bodies and processes working on water related issues, both within the United Nations system and between the United Nations and international financial institutions, drawing on the contributions of other international institutions and civil society to inform inter-governmental decision making. ${ }^{43}$

From Johannesburg to the run up to the Rio+20 Conference the international community has achieved greater international water cooperation and coordination, but not always in a coherent and orderly manner.

In sum, this section highlighted that water governance is a process in which law (and international law) has a transformational role. ${ }^{44}$ Against this conceptual background, the current mobious-web form of global water governance demonstrates that, although some progress has been made from the call for further international water cooperation in Johannesburg back in 2002, more cooperation and more coordination between all actors involved is still needed. The UNCSD is a further step in the development of global governance and the next section will critically assess how water has been dealt with therein.

\section{Water and Rio+20}

\footnotetext{
${ }^{42}$ Johannesburg Plan of Implementation, paras. 25-28, highlighted as priorities achieving safe drinking water, develop IWRM and water efficiency plans, monitor and assess water quantity and water quality in developing countries and economies in transition, and improve water resource management and scientific understanding of the water cycle.

${ }^{43}$ Ibid., para. 29.

${ }^{44}$ International Law has played a role in global water governance, but we are still far away from the establishment of a global water law. In fact, water related rules and obligations have mushroomed, and so have water related institutions. However, obligations tend to be soft and declared in recommendatory terms most of the times, and in most cases institutions are not equipped with enforcement and judicial machineries capable of enforcing such obligations, even if they were "harder". Having said this, some core elements thereof can be found in customary international law.
} 
Twenty years after the United Nations Conference on Environment and Development $(\mathrm{UNCED})^{45}$ States met again in Rio de Janeiro to renew their political commitment to sustainable development and to pave the way for green economy policies in the context of sustainable development. ${ }^{46}$ The outcome of this high-level meeting has been a political document titled The Future We Want, ${ }^{47}$ where strategies to strengthen the institutional structure of sustainable development at a global level and to promote a green economy have been fleshed out. More importantly, an inter-governmental process has been launched to establish a set of Sustainable Development Goals (SDGs) that will build upon the Millennium Development Goals (MDGs). ${ }^{48}$ If somebody was expecting a strong legally binding agreement from the Rio+20 Conference, or an influential set of limited principles, along the lines of the outcome of UNCED in $1992,{ }^{49}$ then that person will most likely be disappointed. However, the UNCSD can be better understood as an international community agenda setting process, where States and other global policymakers and stakeholders agreed on key areas of concern and of action for current and future generations. Perceived in that sense, delegates may not have left Rio +20 completely empty handed. Still, being a process, and one that is only really starting, its success will be judged in years to come.

\footnotetext{
${ }^{45}$ United Nations Conference on Environment and Development (UNCED), Rio de Janeiro, 3-14 June 1992.

${ }^{46}$ United Nations Conference on Sustainable Development (RIO+20), Rio de Janeiro, 20-22 June 2012.

47 The Future We Want, UN General Assembly Resolution 66/288 of 27 July 2012, Annex, UN Doc. A/RES/66/288, 11 September 2012.

${ }^{48} \mathrm{Ibid}$., paras. 245-251.

${ }^{49}$ Agenda 21; the Rio Declaration on Environment and Development (UN Doc. A/CONF.151/6/Rev.1), 31 International Legal Materials (1992), p. 874; Doc. A/CONF.151/26 (Vol. III), Non-legally binding authoritative statement of principles for a global consensus on the management, conservation and sustainable development of all types of forests, 14 August 1992; the United Nations Framework Convention on Climate Change (adopted 9 May 1992, entered into force 21 March 1994), 31 International Legal Materials (1992), p. 822; and the Convention on Biological Diversity, Rio de Janeiro, (5 June 1992, entered into force on 29 December 1993), 31 International Legal Materials (1992), p. 818.
} 
Taking into account the importance that water related matters have acquired in international relations in the last decades,${ }^{50}$ and the stress under which water resources find themselves currently, ${ }^{51}$ it is no surprise that water was on the agenda of the negotiations leading up to the UNCSD. UN-Water, the UN interagency organization created in 2003 to follow up the Johannesburg Plan of Implementation water related commitments, highlighted integrated water resources management (IWRM), water and sanitation, investment in water infrastructure and water-based adaptation to climate change as key elements needed in order to pursue a green economy. ${ }^{52}$ Most of these recommendations were taken on board at the Rio +20 Conference where water (and sanitation) was one of the thematic areas of interest in the context of a renewed commitment on sustainable development and of discourse aiming to move towards a green economy. ${ }^{53}$ A close analysis of the text of The Future We Want related specifically to water and sanitation leads to the following two observations.

On the one hand, the link between water and sustainable development is made very explicit. ${ }^{54}$ This puts water in a special position when advocating for a water specific

\footnotetext{
${ }^{50}$ See supra section 2.

${ }^{51}$ See United Nations Educational, Scientific and Cultural Organization (UNESCO), United Nations World Water Assessment Programme (WWAP), UN-Water United Nations World Water Development Report 4. Volume 1: Managing Water under Uncertainty and Risk (2012).

52 UNCSD Secretariat, Rio+20 Issues Brief no 11: Water (2011), p. 3. See also Water in a Green Economy, A Statement by UN-Water for the UN Conference on Sustainable Development 2012 (Rio+20 Summit), available at http://www.unwater.org/downloads/UNW_RIOSTATEMENT.pdf.

${ }^{53}$ The Future We Want, supra note 47, paras. 119-124. The other thematic areas and cross sectoral issues were: poverty eradication (paras. 105-107); Food security and nutrition and sustainable agriculture (paras. 108-118); Energy (125-129); Sustainable Tourism (paras. 130-131); Sustainable Transport (paras. 132133); Sustainable cities and human settlements (paras. 134-137); Health and population (paras. 138-146); Promoting full and productive employment, decent work for all and social protection (paras. 147-157); Oceans and seas (paras. 158-177); Small Island developing States (paras. 178-180); Least developed countries (para. 181); Landlocked developing countries (para. 182); Africa (paras. 183-184); Regional efforts (para. 185); Disaster risk reduction (paras. 186-189); Climate Change (paras. 190-192); Forests (paras. 193-196); Biodiversity (paras. 197-204); Desertification, land degradation and drought (paras. 205209); Mountains (paras. 210-212); Chemicals and waste (paras. 213-223); Sustainable consumption and production (paras. 224-226); Mining (paras. 227-228); Education (paras. 229-235); Gender equality and women's empowerment (paras. 236-244).

${ }^{54}$ Ibid., para. 119: "We recognize that water is at the core of sustainable development as it is closely linked to a number of key global challenges. We therefore reiterate the importance of integrating water in
} 
SDG. ${ }^{55}$ On the other hand, The Future We Want serves both as a reminder of past water related international commitments and as an agenda setting process for future key water related topics that the international community must face. In terms of reminders, it reiterates the need to meet target 7.C of the MDG by 2015 by halving the amount of people worldwide without access to safe-drinking water and basic sanitation. ${ }^{56}$ It also stresses the importance to continue improving the implementation of IWRM. In terms of agenda setting, three key water related topics stem from the water related paragraphs of The Future We Want: further improve access to water and sanitation; the link between water and ecosystem services; and the relationship between water and climate change.

\subsection{Access to Water and Sanitation}

Starting with the first one, access to safe and affordable drinking water and sanitation is considered a human right that needs to be progressively realized. ${ }^{57}$ Three initial observations can be made here. First, water per se is not a human right; access to safe drinking water and sanitation is the content of this human right that has slowly but steadily been developed by the international community in the last decade. ${ }^{58}$ Second, by referring

sustainable development and underline the critical importance of water and sanitation within the three dimensions of sustainable development."

${ }^{55}$ However, those lobbying for other specific SDG could maintain a similar position for other areas also relevant and crucial for sustainable development.

56 The MDG water related target gives for a mixed picture. In fact, while it has been a successful story in relation to access to safe drinking water by halving the proportion of people without access to improved sources of water, the same cannot be said for sanitation. In fact, despite some progress 2.5 billion in developing countries still lack access to improved sanitation facilities. Further information at http://www.un.org/millenniumgoals/environ.shtml.

57 The Future We Want, supra note 47, para.121.

58 The combination of the Committee on Economic, Social and Cultural Rights, General Comment No. 15: the Right to Water (arts. 11 and 12 of the International Covenant on Economic, Social and Cultural Rights), E/C.12/2002/11, 2003, of Resolutions and Decisions taken by the United Nations Human Right Council (UN Human Rights Council, Decision 2/104, 27 November 2006, adopted without a vote); Human Rights Council, Human Rights and Access to Safe Drinking Water and Sanitation, Resolution 7/22, 28 March 2008 (adopted without a vote); UN HRC- General Assembly, Human Rights and Access to Safe Drinking Water and Sanitation, A/HRC/RES/12/8, 1 October 2009 (adopted without a vote); UN HRC - General Assembly, Human Right and Access to Safe Drinking Water and Sanitation, A/HRC/RES/15/9, 6 October 2010; and 
to "affordable" drinking water, the document clarifies that a human right to water does not mean that water must be given out for free. On the opposite, it promotes quite the opposite message. Delivering water has a cost, but this needs to be affordable in order for the human right to access to water and sanitation to be met. ${ }^{59}$ Third, The Future We Want maintains that:

We reaffirm our commitments regarding the human right to safe drinking water and sanitation, to be progressively realized for our populations with full respect for national sovereignty. ${ }^{60}$

The reference to national sovereignty is a stark reminder that, even if the international community is moving towards a human right to access to water and sanitation, States are still perceived as the dominant players in this field. These observations lead to some further questions: how can a human right to access to water and sanitation be implemented $?^{61}$ Who enjoys such a right and which are the obligations that stem from

UN HRC - General Assembly, The Human Right to Safe Drinking Water and Sanitation, A/HRC/18/L.1, 23 September 2011), and of the United Nations General Assembly, The Human Right to Water and Sanitation, UN Doc. A/64/L.63/rev.1, 2010, has led progressively to the consolidation of a human right to safe drinking water and sanitation. In any case, commentators had argued that the universally accepted human right to life implied a human right to water, because, without the latter, there would be no life. However, this would be the case only if human right to life is considered broadly as providing every human being with the right to have appropriate means of subsistence and a decent standard of life. According to Stephen C. McCaffrey, "A Human Right to Water: Domestic and International Implications", 5 The Georgetown International Environmental Law Review (1992), p. 8 a right to water is implicit within the conceptual notion of adequacy of a standard of living to protect the health and well-being contained in Article 25 of the Universal Declaration of Human Rights.

59 Affordability is one of the key elements of a human right to safe drinking water and sanitation as construed and clarified by the UN Special Rapporteur on the human right to safe drinking water and sanitation.

${ }^{60}$ The Future We Want, supra note 47, para. 121. Emphasis added.

${ }^{61}$ The human right to access to water and sanitation leads to a due diligence obligation upon the bearer of such a right. The obligation will be fulfilled if all necessary legal and political steps to promote such a right are put in place. If, despite such efforts, subjects who should enjoy such a right find themselves in a situation where their human right to water and sanitation is not met, this will not constitute per se a human right violation. For further information about the nature of the human right to water and sanitation and its implementation see Inga Winkler, The Human Right to Water: Significance, Legal Status and Implications for Water Allocation (2012); Peter Gleick, "The Human Right to Water", in 1 Water Policy (1999), p. 487; Pierre Marie Dupuy, "Le droit à l'eau, un droit international?", in EUI Working Paper LAW n 2006/06; Victor Manuel Sanchez, "Hacia un Derecho humano fundamental al agua en el Derecho internacional", 16 Revista Electrónica de Estudios Internacionales (2008). 
having to deliver such a human right ${ }^{62}$ And which are the subjects that are bound by a human right to access to water and sanitation? ${ }^{63}$

\subsection{Water and Ecosystem Services}

The second key water related topic that stems from the UNCSD is the link between water and ecosystem services. ${ }^{64}$ Despite the fact that it may not appear so prominent in the final document, water quality and quantity rely heavily on healthy ecosystems. In the water brief prepared by the UNCSD Secretariat prior to the Rio+20 Conference, payment for ecosystem services was indicated as one of the means to deliver effective water resources management and development. ${ }^{65}$ Taking the above into account, The Future We Want "support[s] actions within respective national boundaries to protect and sustainably manage these ecosystems." ${ }^{66}$ Two immediate questions beg to mind. First, is payment for ecosystem services the only way to promote healthy ecosystems? ${ }^{67}$ This question is relevant not only for water, but also for management policies over other natural resources

\footnotetext{
${ }^{62}$ Being a human right obviously it will be individuals who enjoy a human right to water and sanitation. However, special attention will be devoted to vulnerable groups and in these cases the substantive and procedural elements embedded in the human right to water are strengthened. This is the case for example for indigenous people who must be consulted before any activity takes place that may lead to harmful effects upon water resources within their territories. The UN Special Rapporteur on the human right to safe drinking water and sanitation has clarified that the human right to water and sanitation has a multifaceted content. In particular, this right is about "availability, quality, acceptability, accessibility and affordability." ${ }^{63}$ Primarily this would be the State, but, as we have mentioned when discussing the move from government to governance, see supra note 11, States are not the only, and in some cases, not the key water related players anymore. This is especially the case in those countries where water services have been privatizes. Multinational corporations, or more generally private companies, can be in charge of delivering water and sanitation services, but does this mean that an individual who feels that her human right has been violated can have access to justice against a private party?

${ }^{64}$ The Future We Want, supra note 47, para. 122.

${ }^{65}$ Rio Water Brief, supra note 50, p. 4. The good practice highlighted in the brief was a Payment for Environmental Services pilot project in the Lake Naivasha basin, Kenya, where upstream farmers were rewarded for providing water stewardship on their lands so that downstream flower and vegetable growers had enough good quality water for their activity.

${ }^{66}$ The Future We Want, supra note 47, para. 122.

${ }^{67}$ Payment for ecosystem services is not the silver bullet and there are other measures that States can consider adopting to promote healthy ecosystems. But more generally, it is the application of IWRM policies that, if implemented and enforced properly, should secure the future prosperity of ecosystems.
} 
that look interestingly at the development of payment for ecosystem services. The second question, looking closely at the outcome of the Rio+20 Conference, is whether only actions within national borders will be supported? While this would be a reminder of the still dominant role of national sovereignty, ${ }^{68}$ limiting policies at a national scale seems very problematic and ineffective. If water stems from a transboundary river or a transboundary aquifer, then quality and quantity of that water in the downstream State will depend and rely on ecosystems in the upstream State or in other aquifer States. ${ }^{69}$ To limit ecosystem considerations within borders is neither realistic nor effective. This is not to say that opening payment for ecosystem services to "international waters" would be easy to table and implement, but it is something that needs to be carefully considered.

\subsection{Water and Climate Change}

The third key water related topic is the relationship between water and climate change. It is interesting that climate change is not mentioned directly in the water and sanitation related section of The Future We Want. However, by referring to "the need to adopt measures to address floods, droughts and water scarcity", ${ }^{70}$ the link with climate change, and with adaptation to climate change in particular, is made apparent. This section on water needs to be read in conjunction with the outcome of the UNCSD on climate change itself where " $[\mathrm{P}]$ ersistent drought" is referred to as one of the adverse impacts of climate change already taking place. ${ }^{71}$ Adaptation, in the same section, is considered as "an immediate and urgent global priority". Three questions can be raised when dealing with

\footnotetext{
${ }^{68}$ As mentioned previously in the discussion over a human right to access to water and sanitation.

${ }^{69}$ Ecosystem centred provisions are present in the United Nations Watercourses Convention, supra note 12, art. 20; in the United Nations International Law Commission Draft Articles on the Law of Transboundary Aquifers (annexed to A/RES/63/124), art. 10.

70 The Future We Want, supra note 47, para. 123.

${ }^{71}$ Ibid., para. 190.
} 
the relationship between climate change and water. First, how different is dealing with, for example, a flood prone area if climate change adaptation is added to the picture ${ }^{72}$ Second, are there any lessons that water can learn by the global fight against climate change ${ }^{73}$ Finally, for good water management to become a driver of climate change adaptation, does there need to be also a national, regional and global normative and institutional link between water and climate change ${ }^{74}$

In sum, water and sanitation, water and ecosystem services, and water and climate change are three key areas that The Future We Want has highlighted and that are now firmly on the international community's agenda. Whether these areas will lead to a more coherent global water governance in the future, or make global water governance even more fragmented than what it is already, is yet to be seen. What is clear is that all these water hotspots occur in the context of sustainable development and of the debate over water as a public good.

\section{Water: from a Public Good to a Sustainable Development Goal}

\footnotetext{
${ }^{72}$ The immediate answer would be, not much. In fact, adaptation is often about adopting and implementing environmental law effectively.

${ }^{73}$ One key difference between global climate governance and global water governance is the absence of a policy active epistemic community in the water field, along the lines of the Intergovernmental Panel on Climate Change; see supra note 17. Having said that, despite the fact that international law in the framework of global climate governance has developed a sort of global climate law, differently than what has happened within global water governance, international climate efforts are increasingly fragmented and incoherent.

74 The question here is twofold. On the one hand, once the relationship between water and climate change is proven, then global governance processes should also interact. From an international legal perspective this would mean giving, for example, observer status to water related organisations within international climate change negotiations. However, the problem is identifying the global water institution that could be invited... On the other hand, this question is really about understanding the multifaceted nature of water related challenges. In fact, links are not only with climate change, but with most environmental and non environmental international regimes. One link that has been made in the past is with trade and, according to Pahl-Wostl, Gupta and Petry, supra note 9, efficient global water law needs to interact with other fields of international law.
} 
Access to water (and sanitation) has led to a very heated and polarized debate. On the one hand, some economists have argued that water is not a public good and have criticized those who label it as a basic human right. ${ }^{75}$ On the other hand, other authors do not shy away from considering water a major global public good. ${ }^{76}$ The Future We Want makes it clear that countries signing up to such document consider access to safe drinking water and sanitation a human right that needs to be progressively realized. ${ }^{77}$

Rather than dwelling further on whether water should be considered as global public good or not, water should be considered within the context of sustainable development. As mentioned in The Future We Want itself "water is at the core of sustainable development" ${ }^{78}$ If that is the case, and it is indeed, then water should be recognized as such in the negotiations leading to the definition of SDGs. Water should be scaled up from how it was framed in the MDGs and acquire a self standing role. The water related SDG should not just refer to targets related to access to safe drinking water and sanitation, but should refer to improving water management both at national and global levels. While a goal set by the international community does not lead immediately to tangible and enforceable legal obligations, it still has normative implications. An SDG water related goal would inevitably drive domestic and international efforts towards further cooperation and coordination. The extent to which this may in the future trigger the development of a fully-fledged global water law with obligations and institutions is yet to be seen, but it would be a step in the right direction. As an international agenda

\footnotetext{
${ }^{75}$ See Alex Robson, "A 'public good' is not just something which is 'good for the public'. The abuse of economic terminology in public debate", IPA Review (2007), p. 39: "Often, water seems to be labelled as a public good simply because it is something which members of the public enjoy consuming or consume on a regular basis. Left-wing activists even go as far as to claim that water is a basic human right." Emphasis present in the original.

${ }^{76}$ See Pahl-Wostl, Gupta and Petry, supra note 9, p. 420.

${ }^{77}$ The Future We Want, supra note 47, para. 121.

${ }^{78}$ Ibid., para. 119.
} 
setting process, the Rio +20 Conference should be seen as evidence of an interest of the international community in further linking water and sustainable development. The three water related areas that this paper has identified as arising from The Future We Want: increased access to water and sanitation, water and payment for ecosystem services, and water and climate change, must be understood in the wider context of an emerging global water governance that will ultimately benefit by the establishment of a SDG water related goal. 